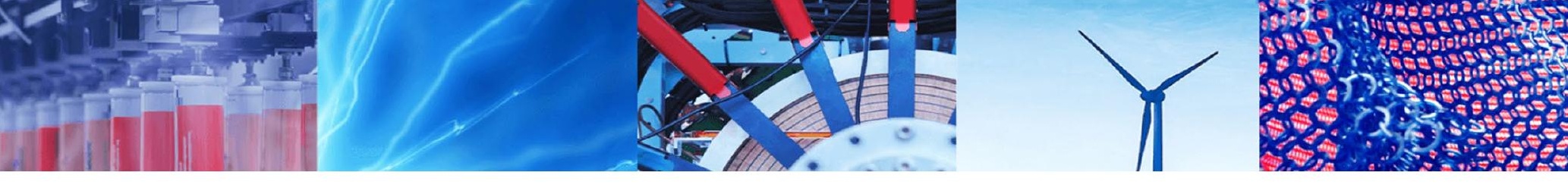

Research Article

\title{
Effects of urban atmospheric particulate matter on higher plants using Lycopersicon esculentum as model species
}

\author{
Katalin Hubai ${ }^{1}$. Nora Kováts ${ }^{1} \cdot$ Gábor Teke $^{2}$ \\ Received: 27 May 2021 / Accepted: 22 July 2021 \\ Published online: 09 August 2021 \\ C The Author(s) 2021 OPEN
}

\begin{abstract}
Atmospheric particulate matter (PM) is one of the major environmental concerns in Europe. A wide range of studies has proved the ecotoxic potential of atmospheric particles. PM exerts chemical stress on vegetation by its potentially toxic constituents; however, relatively few studies are available on assessing phytotoxic effects under laboratory conditions. In our study, aqueous extract of particulate matter was prepared and used for treatment. Experiment was following the procedure defined by the No. 227 OECD Guideline for the Testing of Chemicals: Terrestrial Plant Test. Tomato (Lycopersicon esculentum Mill.) plants were used; elucidated toxicity was assessed based on morphological and biochemical endpoints such as biomass, chlorophyll- $a$ and chlorophyll- $b$, carotenoids, and protein content. Biomass reduction and protein content showed a clear dose-effect relationship; the biomass decreased in comparison with the control (100\%) in all test groups (TG) at a steady rate (TG1: 87.73\%; TG2: 71.77\%; TG3: 67.01\%; TG4: 63.63\%). The tendency in protein concentrations compared to the control was TG1: 113.61\%;TG2: 148.21\% TG3: 160.52\%; TG4: 157.31\%. However, pigments showed a'Janus-faced' effect: nutrient content of the sample caused slight increase at lower doses; actual toxicity became apparent only at higher doses (chlorophyll- $a$ concentration decrease was $84.47 \%$ in TG4, chlorophyll- $b$ was $77.17 \%$, and finally, carotene showed $83.60 \%$ decrease in TG4).
\end{abstract}

Keywords Aerosol ecotoxicity · Vegetative vigour test · Lycopersicon esculentum Mill. · Growth inhibition . Photosynthetic pigments · Protein

\section{Introduction}

Atmospheric particulate matter (PM) is a portion of air pollution and one of the major environmental concerns in Europe [1]. According to the aerodynamic diameter, particles can be classified as PM10 ( $<10 \mu \mathrm{m}$ diameter) and fine aerosols (PM2.5 or PM1). Toxicity of these particles is determined by numerous factors including chemical composition and size. However, classification on physicochemical parameters might be rather difficult; therefore, the general method to group PM is based on diameter such as coarse $\mathrm{PM}<10 \mu \mathrm{m}$ (PM10), fine $\mathrm{PM}<2.5 \mu \mathrm{m}$ (PM2.5), and ultrafine $P M<0.01 \mu \mathrm{m}$ (PM0.1) [2]. While limit values exist for PM10 and PM2.5 fractions in Europe, the significance of ultrafine particles $(\leq 0.1 \mu \mathrm{m}, \mathrm{PM} 0.1)$ has increased as they pose higher environmental risk [3].

Plants are directly exposed to airborne pollutants, enduring a practically lifetime exposure. The deleterious effects of airborne PM on higher plants include morphological, physicochemical, and biochemical alterations [4]. Dry deposition of particles on leaves can negatively influence the first photochemical reactions via shading effect [5]. Physical damage also implies that particles can simply block stomata or alter optical absorption of the leaves [6].

\footnotetext{
$\triangle$ Nora Kováts, kovats@almos.uni-pannon.hu | ${ }^{1}$ Centre for Natural Sciences, University of Pannonia, Egyetem Str. 10, 8200 Veszprém, Hungary. ${ }^{2}$ ELGOSCAR-2000 Environmental Technology and Water Management Ltd., 8184 Balatonfuzfo, Hungary.
}

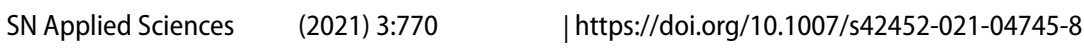


Resulting physiological responses involve impaired growth and photosynthesis, as well as altered transpiration [7].

Particulates might bind potentially phytotoxic compounds which will affect plants by dry or wet deposition [8]. Atmospheric dry deposition occurs via gravitational settling; wet deposition is the washout of both vapour phase and particulate bound chemicals by precipitation [8]. Atmospheric wet deposition is considered a significant removal mechanism of particulate matter, polycyclic aromatic hydrocarbons (PAHs) [9], and metals [10].

PAHs are persistent and ubiquitous organic pollutants which are released into the environment mainly through anthropogenic sources such as vehicular exhaust, biomass burning, waste incineration, or residential heating [11]. Low molecular weight PAHs (consisting of 2-3 aromatic rings) usually migrate in the environment in the gaseous form while heavy molecular weight PAHs are transported by particles [12].

Major source of heavy metals is particulate debris thrown off from brakes. Maiorana et al. [13] found high concentration of potentially toxic heavy metals such as $\mathrm{Al}, \mathrm{Cr}, \mathrm{Zn}$ in experimentally produced brake debris; also, phytotoxicity of these samples was proved. Aquatic toxicity of PM emission generated in different brake systems was also supported [14].

PM and PM-bound chemicals such as PAHs and heavy metals have been reported to cause oxidative stress in plants $[15,16]$. Formation of reactive oxygen species (ROS) can trigger membrane and cell damages [17].

To scavenge excess ROS, plants have evolved an antioxidant defence system including non-enzymatic and enzymatic pathways. Major antioxidant enzymes are ascorbate peroxidase (APX), catalase (CAT), peroxidase (POD), and superoxide dismutase (SOD) [18]. Jing et al. [19] reported that naphthalene exposure resulted in structural alterations of CAT and SOD; also, it bound to the surface of these enzymes. Similar mechanisms were reported for phenanthrene toxicity [15]. Increased levels of CAT and POD were found by Karmakar and Padhy [21] as indicator of stress triggered by PM-bound heavy metals. Increased gene expression of POD and CAT was found in tomato seedlings exposed to heavy metal stress [20].

ROS may also interfere with various sites of the photosynthetic electron transport chain, inhibiting the pigment synthesis process [21]. Decreased chlorophyll content can be experienced at sites with high air pollution level. Air pollutants may cause the degradation of chlorophyll molecule and reduce the efficiency of chloroplasts which in turn affect photosynthetic rate and finally reduce growth rate [22]. Heavy metal stress may also have an inhibitory effect on chlorophyll synthesis [23].

The No. 227 OECD Guideline (hereinafter referred to as 'Guideline') was originally designed to test phytotoxicity of chemicals used in agriculture such as general chemicals, biocides, and crop protection products $[24,25]$. The Guideline was tested and adopted in order to mimic wet deposition and to investigate the effect of water-soluble components of PM [26].

The Guideline recommends the use of following endpoints: biomass, shoot length, and visual symptoms. Olszyk et al. [27] discuss that assessment of vegetative plant growth is generally overemphasized in plant testing protocols.

Present study aimed at determining the phytotoxic effects of urban PM2.5 extract on higher plants using tomato (Lycopersicon esculentum Mill.) as test species. While the Guideline assesses phytotoxicity based on biomass/growth inhibition and visual symptoms, the main objective of this study was to evaluate if inclusion of additional endpoints can be feasible and provide new information. Taking into consideration that biochemical endpoints have proved overly sensitive in a wide range of reports (reviewed by Rai [28]), the following biochemical endpoints were selected: chlorophyll- $a$ and chlorophyll$b$, carotenoids, and protein content. Dose-effect relationships were also analysed to gain better insight into the ecological response of each parameter.

\section{Material and methods}

\subsection{Sample collection and preparation}

PM2.5 (particles with diameter of $2.5 \mu \mathrm{m}$ ) aerosol samples were provided by the Hungarian Air Quality Reference Centre. Samples were collected in Budapest (Hungary), covering a 2-week period (from 25 December 2016 to 06 January 2017). Equipment used was a Digitel (DHA-80) high-volume sampler; samples were continuously collected on Whatman QMA glass fibre filters with diameter of $150 \mathrm{~mm}$. Filters were removed and replaced in every $24 \mathrm{~h}$ and stored in a freezer at $-20 \mathrm{C}$ until use. The halves of each filter were used for extraction. They were cut in pieces and placed in beaker filled with $1000 \mathrm{~mL}$ high-purity water (Synergy ${ }^{\circledR}$ Water Purification System MilliQ $18.2 \mathrm{M} \Omega$ / $\left.\mathrm{cm} @ 25^{\circ} \mathrm{C}\right)$. As such, a composite sample was produced [29]. Pieces were stirred in the beaker several times; then, the beaker was covered. Extraction took $24 \mathrm{~h}$ at room temperature. The extract was filtered through $0.45-\mu \mathrm{m}$ pore size filter (GN-6 membrane, $0.45 \mu \mathrm{m}$ hydrophilic mixed cellulose esters) and stored in conical tubes at $-20 \mathrm{C}$ until use.

Analytical determinations of PAHs and heavy metals were conducted in the Laboratory of the ELGOSCAR-2000 Environmental Technology and Water Management Ltd. (accredited by the /Hungarian/ National Accreditation Authority, 
registration number NAH-1-1278/2015). Concentrations were reported in Kováts et al. [29].

\subsection{Ecotoxicity testing}

The Guideline recommends several crop species for testing (Annex 2). Tomato (Lycopersicon esculentum Mill.) was selected. This species is not only enlisted by the Guideline but has also proved sensitive in experimental studies where detrimental effects of selected PAHs were assessed (e.g. [30, 31]). A widely cultivated, commercially available variety 'Roma' was used [32]. Seeds were purchased from Garafarm Ltd.

Experiment was performed based on the protocol given in the Guideline. Cultivation of test plants and experimental conditions were described in our previous studies [29]. Treatment implied that plants were sprayed with the aerosol water extract using a CONXIN Q1P-CX01-380 portable electric paint spray gun. Treatments started when test plants reached the 4 true leaf stage. Four test groups were set which received treatments as follows:

Test group 1 (TG1): Treatment: Day 0

Test group 2 (TG2): Treatment: Day 0, Day 7

Test group 3 (TG3): Treatment: Day 0, Day 7, Day 14

Test group 3 (TG4): Treatment: Day 0, Day 7, Day 14, Day 21

After exposure, the plants were cut above the cotyledon as close as possible to the planting medium and each individual plant was measured using analytical balance (Kern ABJ 120-AM) to four decimal places. As such, biomass was reported as fresh weight.

Photosynthetic pigment content was determined by UV VIS method based on Bag et al. [33]. 0.2-g sample was taken from the leaf of each plant. These samples were measured using analytical balance (Kern ABJ 120-AM). Leaf segments were homogenized with $15 \mathrm{~mL}$ of $80 \%$ acetone (Fisher Chemicals, $\geq 99.8 \%$, ACS). The homogenized sample mixture was centrifuged ( $3402 \mathrm{~g}, 10 \mathrm{~min}$, Mistral 2000 MSE). Absorbance was measured from the supernatant at $440 \mathrm{~nm}, 645 \mathrm{~nm}, 663 \mathrm{~nm}$, and $750 \mathrm{~nm}$ using UV-VIS Spectrophotometer (Metertech SP8001). Used equations are:

Chl $a=[9.78 * E 663-0.99 * E 645] *[V / 1000 * W]$

$\mathrm{Chl} b=[21.4 * E 645-4.65 * E 663] *[V / 1000 * W]$ where $E$ : extinction values at wavelengths; $V$ : final volume $(25 \mathrm{~mL}) ; W=$ mass of sample $(0.2 \mathrm{~g})$.

Total protein content was determined based on the Lowry method, with slight modifications [34]. For determination, leaf samples taken from each individual plant were used again. Leaves were frozen and homogenized with ice cold mortar and pestle in phosphate buffer $(\mathrm{pH} 7$, solution was adjusted to final desired $\mathrm{pH}$ using $0.1 \mathrm{mmol} / \mathrm{L}$ $\mathrm{HCl}$ or $\mathrm{NaOH}$ ). Composition of the buffer: $1 \mathrm{~L}$ puffer: $2.913 \mathrm{~g}$ $\mathrm{NaH}_{2} \mathrm{PO}_{4}{ }^{*} \mathrm{H}_{2} \mathrm{O}$ and $7.744 \mathrm{~g}$ of $\mathrm{Na}_{2} \mathrm{HPO}_{4}{ }^{*} 7 \mathrm{H}_{2} \mathrm{Og}$ diluted in $18.2 \mathrm{M} \Omega / \mathrm{cm} @ 25^{\circ} \mathrm{C}$ Milli-Q water, chemicals from VWR Chemicals) containing $100 \mu \mathrm{L} 1 \mathrm{mmol} / \mathrm{L}$ EDTA (Lach:ner), $100 \mu \mathrm{L} 0.5 \mathrm{mmol} / \mathrm{L}$ Phenylmethylsulphonyl fluoride (PMSF, PanReach Applichem, $\geq 99 \%)$. Samples were centrifuged for $20 \mathrm{~min}$ at $12300 \mathrm{~g}$ at $4{ }^{\circ} \mathrm{C}$.

\subsection{Statistical analysis}

The analyses were carried out using one way ANOVA in each case. Tukey HSD post hoc tests were performed to reveal pairwise differences. Statistical tests were made in R Statistical Environment [35].

\section{Results}

\subsection{Growth rate}

The biomass decreased comparing to the control (100\%) in all test groups (TG1: 87.73\%; TG2: 71.77\%; TG3: 67.01\%; TG4: 63.63\%). Statistically significant difference was experienced between the number of treatments and the biomass (ANOVA $F=35.65, p=1.11^{*} 10^{-14}$ ). The biomass reduction could be detected after one treatment, but after the third treatment the difference was not significant (Tukey HSD: Control-TG1: $p=0.011$;G1-TG2: $p=0.0005 ;$ TG2-TG3: $p=0.0673$; TG3-TG4 $=0.8851)$, the tendency is shown in Fig. 1.

\subsection{Chlorophyll and carotenoid levels}

The tendency in chlorophyll- $a$ content was in comparison with the control (100\%): TG1: 115.27\%; TG2: 128.59; TG3: 118.47\%; TG4: $84.47 \%$. Chlorophyll-a levels showed marginal nonsignificant differences (Fig. 2a) (chlorophyll$a$ : ANOVA: $F=2.821, p=0.0658$ ). The changes in chlorophyll- $b$ concentration were as follows: TG1: $127.38 \%$;

Car $=[4.69 * E 440-0.268 *(5.13 * E 663+20.41 * E 645] *[V / 1000 * W]$ 


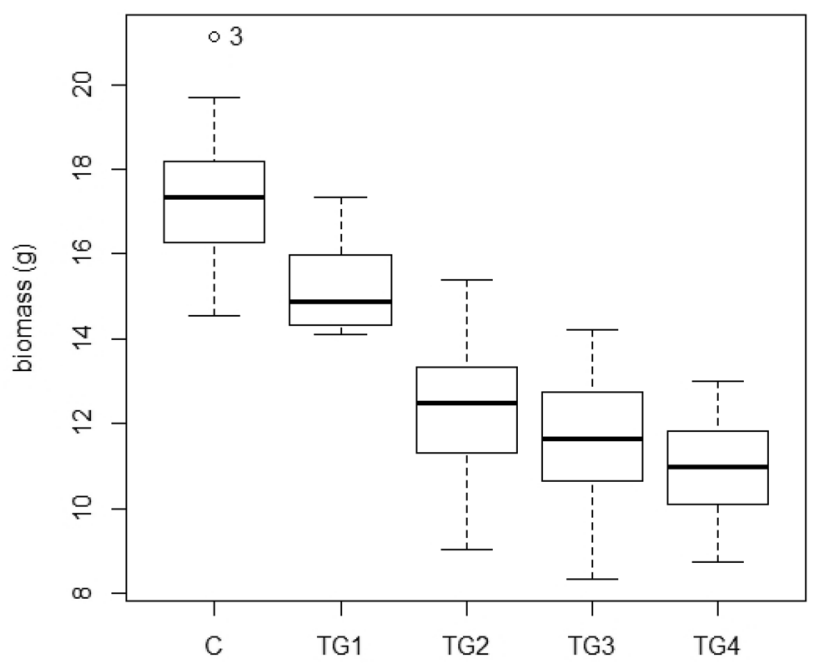

Fig. 1 Biomass in the test groups (TG1, TG2, TG3, and TG4) and in the control (in the boxplot figure, the thick horizontal line gives the median of the $k$ values, the lower and upper edges of the box represent the lower and upper quartiles, and the ends of the moustaches give the range of data without outliers)

142.62\%; TG3: $127.92 \%$; TG4: 77.17\%. Significant difference was found between TG 2 and TG4 chlorophyll- $b$ concentrations (Fig. 2b) (ANOVA: $F=4.093, p=0.0211$, Tukey HSD: TG2-TG4: $p=0.02022$ ). The amount of carotene was compared to the control (100\%): TG1: $108.92 \%$; TG2: 111.44\%; TG3: $107.63 \%$ and TG4: $83.60 \%$. For carotenoid levels, some tendency is seen in Fig. 2c, but no statistically significant difference could be obtained (ANOVA: $F=2.246 ; p=0.116$ ).

Chlorophyll- $a$ and chlorophyll- $b$ ratio showed the following differences in comparison with the control (100\%): TG1: 89.04\% TG2: 88.56\%; TG3: 91.38\%; TG4: $108.12 \%$ (Fig. 2d). Statistically significant difference could be experienced (ANOVA: $F=5.728, p=0.00604$ ). There were significant differences between TG2 and TG4 (Tukey HSD $p=0.01136$ ), TG1 and TG4 (Tukey HSD $p=0.01364$ ), and TG3 and TG4 (Tukey HSD $p=0.0422$ ).

\subsection{Protein content}

The changes in protein concentrations in comparison with the control were TG1: $113.61 \%$; TG2: $148.21 \%$ TG3: 160.52\%; TG4: $157.31 \%$. Protein concentrations show significant response (ANOVA: $F=7.661 p=0.0000678$, Tukey HSD: control-TG2: $p=0.0065$; control-TG3: $p=0.00036$; control-TG4: $p=0.00136$; TG1-TG3: $p=0.0136$ ) (Fig. 3). Analysing the curve, it is an 'all or nothing' stressor-response relationship pattern, when gradual development of the ecotoxic effects can be expected in the range between the concentration causing minimum and the one causing significant toxic effect [36].

\section{Discussion}

When PM phytotoxicity is assessed using multiple test endpoints, biomass reduction is the most sensitive measured effect in the vast majority of the studies [37]. Storch-Böhm et al. [38] evaluated the sensitivity of different parameters when test plants were exposed to diesel engine exhaust. Biomass was more sensitive endpoint than biochemical markers; however, the authors discussed that it could be a late response.

Lower growth rate can be linked to the toxic effect of one or more pollutants being present in the extract. Daresta et al. [32] reported that exposure to atmospheric PAHs resulted in the reduced growth of tomato seedlings and increased ROS levels in plant cells. Pašková et al. [39] confirmed the negative effect of three PAHs and their $\mathrm{N}$-heterocyclic derivates on the germination and growth of seedlings of mustard, barley, and common bean. Desalme et al. [40] also reported biomass decrease in clover following treatment with another $\mathrm{PAH}$, phenanthrene.

Decreased growth rate can be partially attributed to changes at different structural levels of the photosynthetic apparatus [41]. In the experiment of Oguntimehin et al. [30], inhibition of photosynthetic carbon assimilation was reported when effect of fluoranthene was assessed on cherry tomato plants (Lycopersicon esculentum Mill).

During stress, plants suppress some life functions because their stress-signalling networks need energy for survive; one of these functions is the photosynthetic capacity. The increase in biomass depends on the quantity of bound carbon dioxide during photosynthesis $[42,43]$. Molecular biological studies demonstrated downregulation of photosynthetic gene expression by abiotic stress, and consequently, this regulation also decreases plant growth [44] We demonstrated that PAHs could reduce the biomass and the decrease in biomass was significantly higher with increasing the number of treatments; after the fourth treatment, the biomass compared to the control was $63.63 \%$.

The most common effect of air pollution is lower chlorophyll (Chl) content, yellowing of the leaves, changes in the structure of chloroplast and thylakoid membrane; these changes can be associated with reducing or inhibiting the photosynthetic activity of the plant $[45,46]$. The most sensitive part of photosynthetic apparatus is the PSII; the environmental stress can cause changes in its structure [47]. Jin et al. [48] reported that phenanthrene, a widely distributed PAH, inhibited photosystem II (PSII) 
a.)

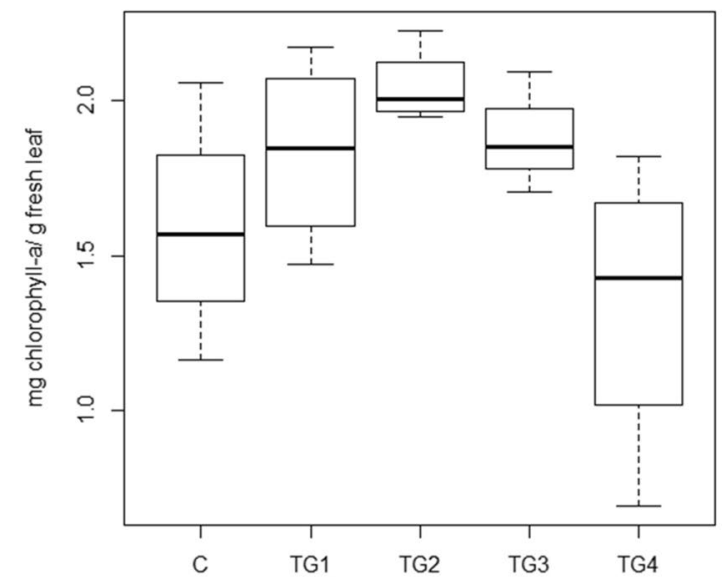

c.)

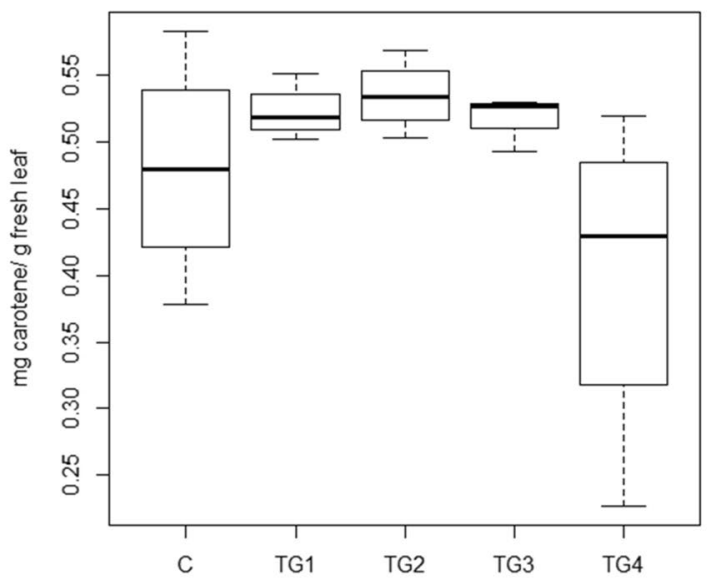

b.)

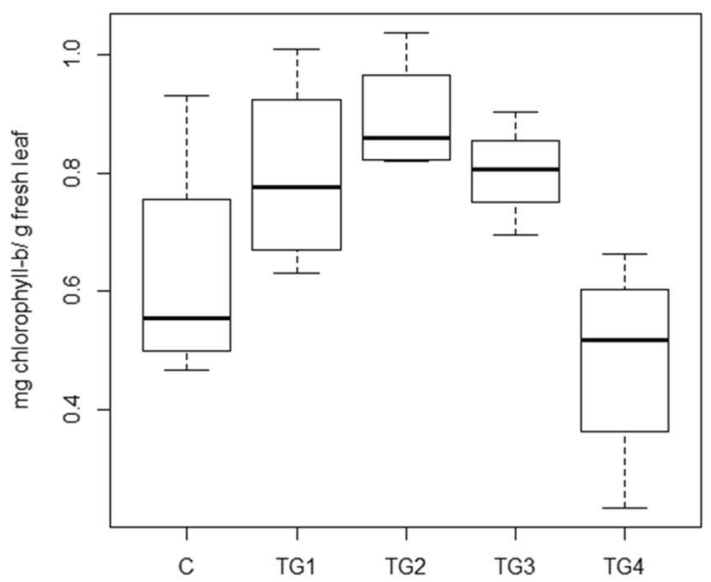

d.)

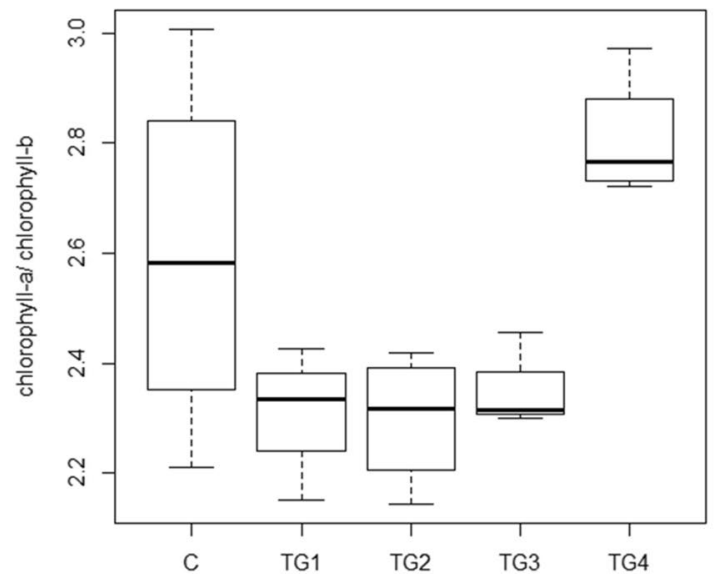

Fig. 2 a Chlorophyll- $a$, b chlorophyll-b, c carotene content, d chlorophyll-a/chlorophyll- $b$ ratio in the test groups (TG1, TG2, TG3, and TG4) and in the control

activity, also blocking photosynthetic electron transport. Under stress, chlorophyll pigments may undergo several photochemical reactions, e.g. oxidation, reduction, or reversible bleaching $[49,50]$.

Decrease in chlorophyll levels was found as response to foliar application of PAHs in most of the studies [51, 52]. Tomar and Jajoo [53] observed that FLT treatment elucidated significant reduction in $\mathrm{Chl} a$ and $\mathrm{Chl} b$ and also a reduction in carotenoid levels.

In our experiment, significant decrease in pigment content could be seen only after the fourth treatment, $84.47 \%$ of the control value in case of $\mathrm{Chl} a$ and $77.17 \%$ in case of $\mathrm{Chl} b$. Low concentrations (low number of treatments) rather elucidated a slight increase (Chl $a$ : TG1: 115.27\%, TG2: 128.59, TG3: 118.47\%; Chl b: TG1: 127.38\%, 142.62\%,
TG3: $127.92 \%)$. It should be stressed that the above-mentioned studies applied individual, definitely toxic PAHs while in our treatments a complex cocktail of chemicals was used in the form of an aerosol extract.

Similar phenomenon was found in our previous study [54] when seasonal pattern of rural particulate matter was investigated. It was explained by the nutrient content $(\mathrm{N}$, $\mathrm{S}$, and microelements) which might mask the toxic effect of the sample. Atmospheric aerosol particles and/or their aqueous extracts contain important plant nutrients in considerable amount, such as ammonium, nitrate, and sulphate [55] as well as Ca, Mg, and K [56].

Our findings are in line with previous findings of Tripathi and Gautam [57], as they reported that Mangifera indica leaves exposed to air pollution showed an increase (12.8\%) 


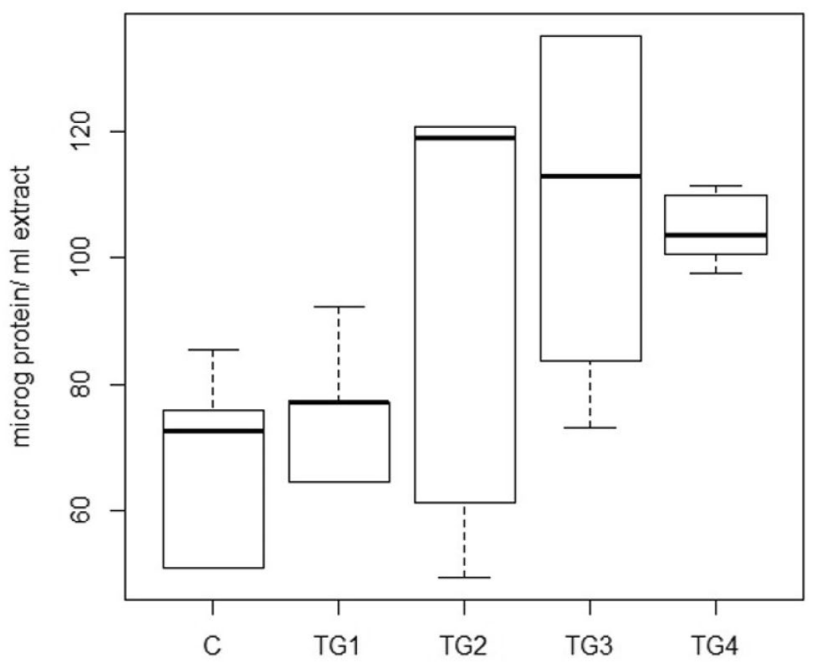

Fig. 3 Protein content in the test groups (TG1, TG2, TG3, and TG4) and in the control

in chlorophyll content. Increase in content of chlorophyll$a$, chlorophyll-b, total chlorophyll, and carotenoid in Albizia lebbeck and Callistemon citrinus was reported by Seyyednejad et al. [58].

The chloroplast also contains carotenoids which are associated with the thylakoids [59]. Carotenoids are part of the non-enzymatic defence system; they can detoxify various forms of ROS [60]. They play a particularly important role in keeping the integrity of the photosynthetic apparatus. In study of MacDonald et al. [61], tomato seeds were treated with $\beta$-carotene; these plants had higher biomass, larger leaf surface and better photosynthetic activity.

Shen et al. [62] showed that carotenoids were amongst the most effective antioxidants under PAH pollution. The higher amount of accumulated carotenoids outside of the thyalkoids plays an essential role in the protection of cells, and they are important stress responses [63]. Our results showed that similar to the chlorophyll content, the amount of carotenoids was increased in TG1-TG3 (TG1: $108.92 \%$; in TG2: 111.44\%; in TG3: $107.63 \%$ ); only the fourth treatment resulted in lower concentration in comparison with the control $(83.60 \%)$. High total carotenoid concentration is a well-recognized plant response to stress [64]. A similar pattern was obtained in a study of Deniz [65], showing that air pollution by a thermal power plant caused an increase in total carotenoid content. The low carotenoid values after the fourth treatment could be explained by Petrova et al. [66], stating that the resistance, adaptation of plants to high level of air pollution in the environment, can be characterized with the changes in photosynthetic pigment content.

In general, this'Janus-faced' effect occurs in cases where the sample contains both nutrients and toxic compounds.
Nutrients are supposed to mask the toxic effect at low concentrations [67]. In addition to higher plants, bacteria showed similar concentration-response pattern when aqueous extracts of ash from forest fires were tested using the bioluminescence inhibition assay [68]. Analytical measurements demonstrated that important nutrients were present ( $\mathrm{Ca}, \mathrm{S}, \mathrm{Mg}, \mathrm{K}$ and $\mathrm{Na}$ ), but also toxic PAHs. At low concentrations, higher bacterial activity (higher luminescence) was found, but at higher concentrations light emittance of the test bacteria decreased.

Chlorophyll $a / b$ ratio is a sign of the functional pigment apparatus and light adjustment, and the total chlorophyll contents characterize the "greenness" in plants [69]. Our results demonstrated that chlorophyll $a / b$ ratio was lower after the treatments than in the control, except for TG4. With leaf ageing, the decomposition of chlorophyll- $a$ is faster than chlorophyll- $b$ [70] that can be responsible for the lower chlorophyll $a / b$ ratio after the treatments. This suggests that the phytotoxic effect of PAHs causes similar changes in pigment content than leaf ageing; chlorophyll $a / b$ may be a sensitive parameter to indicate PAH stress [71].

The important influences of ROS have been reported in many studies [62]; it has control and regulation effect on plant life cycle [72]. ROS are produced under optimal conditions but during stress the rate of production increases.

ROS levels and oxidative stress could be indicated with proteins; they are considered consistent indicators of the controlled modulation of changes in plants cells [73]. We found in this study that in stressed leaves the amount of protein was higher than in control plants (TG1: 113.61\%; TG2: $148.21 \%$ TG3: $160.52 \%$; TG4: $157.31 \%$.); it could be an adaptive mechanism for plants' resistance to PAHs. The higher amount could be explained by several reasons; probably the plants synthetize more proteins for replace the damaged proteins or the higher production of antioxidant enzymes [74]. Detoxification-related and ROS scavenging protective proteins can also accumulate and they mitigate harmful effects of stress on cellular microenvironment [75].

\section{Conclusions}

Plants are exposed to an ever-increasing level of atmospheric pollution. In order to study phytotoxic effects and to understand concentration-effect relationships under laboratory-controlled conditions, in our study Lycopersicon esculentum Mill. plants were exposed to aqueous extract of urban aerosol samples. The No. 227 OECD Guideline was adopted and modified, to include additional endpoints such as chlorophyll- $a$ and chlorophyll- $b$, carotenoids, and protein levels. 
Different endpoints showed different concentration-effect patterns. Biomass seems to reflect the actual toxic effect of the sample, as significant difference could be experienced already after the first treatment. This endpoint is already included in the Guideline and gives an easy-to measure indicator. An additional endpoint, protein content also showed appropriate sensitivity.

Considering photosynthetic pigments, the concentration-effect relationship observed was a typical 'stimulative effect at low concentration, inhibition at higher concentration' pattern. This is a typical stressor-response pattern occurring when the sample contains nutrients which might mask the toxic effect at low concentrations. The simultaneous application of different endpoints seems to give a complex characterization of the chemical mixture atmospheric particulates might carry.

The OECD Guideline was adopted to treat test plants with the aqueous extract of atmospheric PM. Following the protocol, clear concentration-effect responses could be gained which help to get deeper insight into the phytotoxicity mechanisms exerted by particulate air pollution.

Acknowledgements The authors thank the Hungarian Air Quality Reference Centre for the aerosol samples. Special thanks go to the ELGOSCAR-2000 Environmental Technology and Water Management Ltd. (Head Office: 164 Soroksari u. H-1095 Budapest, Laboratory: $\mathrm{H}-8184$ Balatonfuzfo) for analytical measurements.

Authors' contributions NK contributed to the design of the study, was responsible for funding acquisition and project administration, and drafted the initial manuscript. $\mathrm{KH}$ equally contributed to the design of the study, led laboratory testing, and drafted the initial manuscript. GT was also responsible for the measurements and data analysis.

Funding This work was supported by the TKP2020-IKA-07 project financed under the 2020-4.1.1-TKP2020 Thematic Excellence Programme by the National Research, Development and Innovation Fund of Hungary.

Data availability Data generated during the study are included in the manuscipt.

\section{Declarations}

Conflict of interest The authors declare that they have no conflict of interest.

Ethical approval This article does not contain any studies with human participants or animals performed by any of the authors.

Consent to participate Not applicable.

Consent to publish Not applicable.

Open Access This article is licensed under a Creative Commons Attribution 4.0 International License, which permits use, sharing, adaptation, distribution and reproduction in any medium or format, as long as you give appropriate credit to the original author(s) and the source, provide a link to the Creative Commons licence, and indicate if changes were made. The images or other third party material in this article are included in the article's Creative Commons licence, unless indicated otherwise in a credit line to the material. If material is not included in the article's Creative Commons licence and your intended use is not permitted by statutory regulation or exceeds the permitted use, you will need to obtain permission directly from the copyright holder. To view a copy of this licence, visit http://creativecommons. org/licenses/by/4.0/.

\section{References}

1. Vicente ED, Alves CA (2018) An overview of particulate emissions from residential biomass combustion. Atmos Res 199:159-185. https://doi.org/10.1016/j.atmosres.2017.08.027

2. Gangwar RS, Bevan GH, Palanivel R, Das L, Rajagopalan S (2020) Oxidative stress pathways of air pollution mediated toxicity: recent insights. Redox Biol 34:101545. https://doi.org/10.1016/j. redox.2020.101545

3. Kumar P, Kalaiarasan G, Porter AE, Pinna A, Kłosowski MM et al (2021) An overview of methods of fine and ultrafine particle collection for physicochemical characterisation and toxicity assessments. Sci Total Environ 756:143553. https://doi.org/10. 1016/j.scitotenv.2020.143553

4. Kończak B, Cempa M, Pierzchała $Ł$, Deska M (2021) Assessment of the ability of roadside vegetation to remove particulate matter from the urban air. Environ Pollut 268:115465. https://doi. org/10.1016/j.envpol.2020.115465

5. Fusaro L, Salvatori E, Winkler A, Frezzini MA, De Santis E (2021) Urban trees for biomonitoring atmospheric particulate matter: An integrated approach combining plant functional traits, magnetic and chemical properties Ecol. Indic 126:107707. https:// doi.org/10.1016/j.ecolind.2021.107707

6. Przybysz A, Sæbø A, Hanslin HM, Gawroński SW (2014) Accumulation of particulate matter and trace elements on vegetation as affected by pollution level, rainfall and the passage of time. Sci Total Environ 481:360-369. https://doi.org/10.1016/j.scitotenv. 2014.02.072

7. Oksanen O, Kontunen-Soppela S (2021) Plants have different strategies to defend against air pollutants. Curr Opin Environ Sci Health 19:100222. https://doi.org/10.1016/j.coesh.2020.10. 010

8. Grantz DA, Garner JHB, Johnson DW (2003) Ecological effects of particulate matter. Environ Int 29:213-239. https://doi.org/10. 1016/S0160-4120(02)00181-2

9. Zang F, Wang H, Zhao C, Nan Z, Wang S et al (2021) Atmospheric wet deposition of trace elements to forest ecosystem of the Qilian Mountains, northwest China. CATENA 197:104966. https:// doi.org/10.1016/j.catena.2020.104966

10. Guo L-C, Bao L-J, She J-W, Zeng EZ (2014) Significance of wet deposition to removal of atmospheric particulate matter and polycyclic aromatic hydrocarbons: a case study in Guangzhou. China Atmos Environ 83:136-144. https://doi.org/10.1016/j. atmosenv.2013.11.012

11. Liu H-L, Zhou J, Li M, Obrist D, Wang X-Z, Zhou J (2021) Chemical speciation of trace metals in atmospheric deposition and impacts on soil geochemistry and vegetable bioaccumulation near a large copper smelter in China. J Hazard Mater 413:125346. https://doi.org/10.1016/j.jhazmat.2021.125346

12. Krzyszczak A, Czech B (2021) Occurrence and toxicity of polycyclic aromatic hydrocarbons derivatives in environmental 
matrices. Sci Total Environ 788:147738. https://doi.org/10.1016/j. scitotenv.2021.147738

13. Sun K, Song Y, He F, Jing M, Tang J, Liu R (2021) A review of human and animals exposure to polycyclic aromatic hydrocarbons: health risk and adverse effects, photo-induced toxicity and regulating effect of microplastics. Sci Total Environ 773:145403. https://doi.org/10.1016/j.scitotenv.2021.145403

14. Maiorana S, Teoldi F, Silvani S, Mancini A, Sanguineti A et al (2019) Phytotoxicity of wear debris from traditional and innovative brake pads. Environ Int 123:156-163. https://doi.org/10.1016/j.envint. 2018.11.057

15. Volta A, Sforzini S, Camurati C, Teoldi F, Maiorana S et al (2020) Ecotoxicological effects of atmospheric particulate produced by braking systems on aquatic and edaphic organisms. Environ Int 137:105564. https://doi.org/10.1016/j.envint.2020.105564

16. Sharma P, Jha AB, Dubey RS, Pessarakli M (2012) Reactive oxygen species, oxidative damage, and antioxidative defense mechanism in plants under stressful conditions. J Bot 2012:1-26. https://doi. org/10.1155/2012/217037

17. He F, Liu Q, Jing $M$, Wan J, Huo $C$ et al (2021) Toxic mechanism on phenanthrene-induced cytotoxicity, oxidative stress and activity changes of superoxide dismutase and catalase in earthworm (Eisenia foetida): a combined molecular and cellular study. J Hazard Mater 418:126302. https://doi.org/10.1016/j. jhazmat.2021.126302

18. Piacentini D, Falasca G, Canepari S, Massimi L (2019) Potential of PM-selected components to induce oxidative stress and root system alteration in a plant model organism. Environ Int 132:105094. https://doi.org/10.1016/j.envint.2019.105094

19. Guo Z, Lv J, Dong X, Du N, Piao F (2021) Gamma-aminobutyric acid improves phenanthrene phytotoxicity tolerance in cucumber through the glutathione-dependent system of antioxidant defense. Ecotox Environ Safe 217:112254. https://doi.org/10. 1016/j.ecoenv.2021.112254

20. Jing M, Han G, Wan J, Zhang S, Yang J et al (2020) Catalase and superoxide dismutase response and the underlying molecular mechanism for naphthalene. Sci Total Environ 736:139567. https://doi.org/10.1016/j.scitotenv.2020.139567

21. Karmakar D, Padhy PK (2019) Metals uptake from particulate matter through foliar transfer and their impact on antioxidant enzymes activity of S. robusta in a tropical forest, West Bengal. India Arch Environ Con Tox 76:605-616. https://doi.org/10. 1007/s00244-019-00599-9

22. Khanna K, Jamwal VL, Kohli SK, Gandhi SG, Ohri P et al (2019) Plant growth promoting rhizobacteria induced $\mathrm{Cd}$ tolerance in Lycopersicon esculentum through altered antioxidative defense expression. Chemosphere 217:463-474

23. Ahammed GJ, Wang MM, Zhou YH, Xia XJ, Mao WH et al (2012) The growth, photosynthesis and antioxidant defense responses of five vegetable crops to phenanthrene stress. Ecotox Environ Safe 80:132-139. https://doi.org/10.1016/j.ecoenv.2012.02.015

24. Kaur M, Nagpal AK (2017) Evaluation of air pollution tolerance index and anticipated performance index of plants and their application in development of green space along the urban areas. Environ Sci Pollut Res 24:18881-18895. https://doi.org/10.1007/ s11356-017-9500-9

25. Khanna K, Jamwal VL, Gandhi SG, Ohri P, Bhardwaj R (2019) Metal resistant PGPR lowered Cd uptake and expression of metal transporter genes with improved growth and photosynthetic pigments in Lycopersicon esculentum under metal toxicity. Sci Rep 9:5855. https://doi.org/10.1038/s41598-019-41899-3

26. Boutin C, Aya KL, Carpenter D, Thomas PJ, Rowland O (2012) Phytotoxicity testing for herbicide regulation: shortcomings in relation to biodiversity and ecosystem services in agrarian systems. Sci Total Environ 415:79-92. https://doi.org/10.1016/j.scitotenv. 2011.04.046
27. Carpenter C, Boutin C, Allison JE (2013) Effects of chlorimuron ethyl on terrestrial and wetland plants: levels of, and time to recovery following sublethal exposure. Environ Pollut 172:275282. https://doi.org/10.1016/j.envpol.2012.09.007

28. Kováts N, Horváth E, Eck-Varanka B, Csajbók E, Hoffer A (2017) Adapting the vegetative vigour terrestrial plant test for assessing ecotoxicity of aerosol samples. Environ Sci Pollut Res 24:1529115298. https://doi.org/10.1007/s11356-017-9103-5

29. Olszyk D, Pfleeger T, Lee EH, Plocherz M (2010) Phytotoxicity assay for seed production using Brassica rapa L. Integr Environ Asses 6(4):725-734. https://doi.org/10.1002/ieam.89

30. Rai PK (2016) Impacts of particulate matter pollution on plants: Implications for environmental biomonitoring. Ecotox Environ Safe 129:120-136. https://doi.org/10.1016/j.ecoenv.2016.03.012

31. Kováts N, Hubai K, Diósi D, Sainnokhoi TA, Hoffer A et al (2021) Sensitivity of typical European roadside plants to atmospheric particulate matter. Ecol Indic 124:107428. https://doi.org/10. 1016/j.ecolind.2021.107428

32. Oguntimehin I, Eissa F, Sakugawa H (2010) Negative effects of fluoranthene on the ecophysiology of tomato plants (Lycopersicon esculentum Mill) Fluoranthene mists negatively affected tomato plants. Chemosphere 78:877-884. https://doi.org/10. 1016/j.chemosphere.2009.11.030

33. Ahammed GJ, Yuan HL, Ogweno JO, Zhou YH, Xia XJ (2012) Brassinosteroid alleviates phenanthrene and pyrene phytotoxicity by increasing detoxification activity and photosynthesis in tomato. Chemosphere 86:546-555. https://doi.org/10.1016/j.chemo sphere.2011.10.038

34. Daresta $B E$, Italiano $F$, de Gennaro $G$, Trotta $M$, Tutino $M$, Veronico $P$ (2015) Atmospheric particulate matter (PM) effect on the growth of Solanum lycopersicum cv. Roma plants Chemosphere 119:3742. https://doi.org/10.1016/j.chemosphere.2014.05.054

35. Bag N, Palni L, Chandra S, Nandi S (2012) Somatic embryogenesis in "maggar" bamboo (Dendrocalamus hamiltonii) and field performance of regenerated plants. Curr Sci 102(9):1279-1287

36. Peterson GL (1983) Determination of total protein. Methods Enzymol 91:86-105. https://doi.org/10.1016/S0076-6879(83)91014-5

37. R Development Core Team (2017) R: a language and environment for statistical computing. R Foundation for Statistical Computing, Vienna, Austria. URL http://www.R-project.org/.

38. USEPA (2000) Method guidance and recommendations for whole effluent toxicity (WET) testing (40 CFR Part 136). EPA 821-B-00004. U.S. Environmental Protection Agency, Office of Water

39. Pavlík M, Pavlíková D, Zemanová V, Hnilička F, Urbanová V, Szákova $J$ (2012) Trace elements present in airborne particulate matterStressors of plant metabolism. Ecotox Environ Safe 79:101-107. https://doi.org/10.1016/j.ecoenv.2011.12.009

40. Storch-Böhm RF, Somensi CA, Cotelle S, Deomar-Simoes MJ, Poyer-Radetski L et al (2020) Sensitivity of different parameters for selection of higher plants in urban afforestation: exposure of Guabiroba (Campomanesia xanthocarpa O. Berg.) to diesel engine exhaust. Environ Pollut 265:114675. https://doi.org/10.1016/j. envpol.2020.114675

41. Pašková $V$, Hilschrová $K$, Feldmannová $M$, Bláha L (2006) Toxic effects and oxidative stress in higher plants exposed to polycyclic aromatic hydrocarbons and their N-heterocyclic derivatives. Environ Toxicol Chem 25:3238-3245. https://doi.org/10.1897/ 06-162R.1

42. Desalme D, Binet P, Epron D, Bernard N, Gilbert D et al (2011) Atmospheric phenanthrene pollution modulates carbon allocation in red clover (Trifolium pratense L.). Environ Pollut 159:27592765. https://doi.org/10.1016/j.envpol.2011.05.015

43. Xiong T, Zhang T, Dumat C, Sobanska S, Dappe V et al (2019) Airborne foliar transfer of particular metals in Lactuca sativa L.: translocation, phytotoxicity, and bioaccessibility. Environ Sci Pollut Res 26:20064-20078. https://doi.org/10.1007/s11356-018-3084-x 
44. Ahuja I, de Vos RC, Bones AM, Hall RD (2010) Plant molecular stress responses face climate change. Trends Plant Sci 15:664-674. https://doi.org/10.1016/j.tplants.2010.08.002

45. Skirycz A, Inze D (2010) More from less: plant growth under limited water. Curr Opin Biotechnol 21:197-203. https://doi.org/10. 1016/j.copbio.2010.03.002

46. Osakabe Y, Osakabe K, Shinozaki K (2013) Plant environmental stress responses for survival and biomass enhancement. Clim Change Plant Abiotic Stress Toler. https://doi.org/10.1002/97835 27675265.ch04

47. Droppa M, Horváth G (1990) The role of copper in photosynthesis. Plant Sci 9:111-123. https://doi.org/10.1080/07352689009382284

48. Yruela I (2005) Copper in plants. Braz J Plant Physiol 17:145-146. https://doi.org/10.1590/S1677-04202005000100012

49. Kreslavski VD, Carpentier R, Klimov VV, Murata N, Allakhverdiev SI (2007) Molecular mechanisms of stress resistance of the photosynthetic apparatus. Biochem Moscow Suppl Ser A 1:185-205. https://doi.org/10.1134/S1990747807030014

50. Jin L, Che X, Zhang Z, Li Y, Gao H, Zhao S (2017) The mechanisms by which phenanthrene affects the photosynthetic apparatus of cucumber leaves. Chemosphere 168:1498-1505. https://doi.org/ 10.1016/j.chemosphere.2016.12.002

51. Giri S, Shrivastava D, Deshmukh K, Dubey P (2013) Effect of air pollution on chlorophyll content of leaves. Curr Agric Res J 1:93-97. https://doi.org/10.12944/CARJ.1.2.04

52. Rahmawati N, Rosmayati D, Basyuni M (2014) Chlorophyll content of soybean as affected by foliar application of ascorbic acid and inoculation of arbuscular mycorrhizal fungi in saline soil. Int J Sci Technol Res 3(7):127-131

53. Oguntimehin I, Sakugawa $\mathrm{H}$ (2008) Fluoranthene fumigation and exogenous scavenging of reactive oxygen intermediates (ROI) in evergreen Japanese red pine seedlings (Pinus densiflora Sieb. Et. Zucc.). Chemosphere 72:747-754. https://doi.org/10.1016/j. chemosphere.2008.03.022

54. Desalme D, Binet P, Bernard N, Gilbert D, Toussaint ML, Chiapusio G (2011) Atmospheric phenanthrene transfer and effects on two grassland species and their root symbionts: a microcosm study. Environ Exp Bot 71:146-151. https://doi.org/10.1016/j.envexpbot. 2010.11.009

55. Tomar RS, Jajoo A (2014) Fluoranthene, a polycyclic aromatic hydrocarbon, inhibits light as well as dark reactions of photosynthesis in wheat (Triticum aestivum). Ecotox Environ Safe 109:110 115. https://doi.org/10.1016/j.ecoenv.2014.08.009

56. Kováts N, Fábián VA, Hubai K, Diósi D, Sainnokhoi TA et al (2020) Seasonal differences in rural particulate matter ecotoxicity. Aerosol Sci Eng 4:169-177. https://doi.org/10.1007/ s41810-020-00063-5

57. Lanz VA, Prevot ASH, Alfarra MR, Weimer S, Mohr C et al (2010) Characterization of aerosol chemical composition with aerosol mass spectrometry in Central Europe: an overview. Atmos Chem Phys 10:10453-10471. https://doi.org/10.5194/ acp-10-10453-2010

58. Deng XL, Shi CE, Wu BW, Yang YJ, Jin Q et al (2016) Characteristics of the water-soluble components of aerosol particles in Hefei, China. J Environ Sci 42:32-40. https://doi.org/10.1016/j.jes.2015. 07.010

59. Tripathi AK, Gautam M (2007) Biochemical parameters of plants as indicators of air pollution. J Environ Biol 28:127-132

60. Seyyedneja SM, Niknejad M, Yusefi M (2009) Study of air pollution effects on some physiology and morphology factors of Albizia lebbeck in high temperature condition in Khuzestan. J Plant Sci 41:122-126

61. Thambavani DS, Kumar RS (2011) The monthly changes of chloroplast pigments content in selected plant species exposed to cement dust pollution. J Res Biol 8:660-666
62. Dat JF, Lopez-Delgado H, Foyer CH, Scott IM (2000) Effects of salicylic acid on oxidative stress and thermotolerance in Tobacco. $J$ Plant Physiol 156(5-6):659-665. https://doi.org/10.1016/S01761617(00)80228-X

63. MacDonald MT, Lada RR, Robinson AR, Hoyle J (2009) Seed preconditioning with natural and synthetic antioxidants induces drought tolerance in tomato seedlings. Hort Sci 44:1323-1329

64. Shen Y, Li J, Gu R, Yue L, Wang H et al (2018) Carotenoid and superoxide dismutase are the most effective antioxidants participating in ROS scavenging in phenanthrene accumulated wheat leaf. Chemosphere 197:513-525. https://doi.org/10.1016/j.chemo sphere.2018.01.036

65. Sun T, Yuan H, Cao H, Yazdani M, Tadmor Y, Li L (2018) Carotenoid metabolism in plants: the role of plastids. Mol Plant 11(1):58-74. https://doi.org/10.1016/j.molp.2017.09.010

66. Hendry GAF, Price AH (1993) Stress indicators: chlorophylls and carotenoids. In: Hendry GAF, Grime JP (eds) Methods in comparative plant ecology. Chapman Hall, London, pp 148-152

67. Deniz M (2010) Effect of thermal power plant pollution on mineral nutrition and antioxidative defence mechanism on eucalyptus and morus species. Dissertation, Çukurova University Institute of Natural and Applied Sciences Department of Biology, Adana, Turkey

68. Petrova S, Todorova K, Dakova M, Mehmed E, Nikolov B et al (2017) Photosynthetic pigments as parameters/indicators of tree tolerance to urban environment (Plovdiv, Bulgaria). Ecol Balk 9(1):53-62

69. Silva V, Pereira JL, Campos I, Keizer JJ, Gonçalves F, Abrantes N (2015) Toxicity assessment of aqueous extracts of ash from forest fires. CATENA 135:401-408. https://doi.org/10.1016/j.catena.2014. 06.021

70. Netto ATT, Campostrini E, De-Oliveira JG, Bressan-Smith RE (2005) Photosynthetic pigments nitrogen, chlorophyll fluorescence and SPAD-502 readings in coffee leaves. Sci Hortic 4:199-209. https:// doi.org/10.1016/j.scienta.2004.08.013

71. Wagh ND, Shukla PV, Tambe SB, Ingle ST (2006) Biological monitoring of roadside plants exposed to vehicular pollution in Jalgaon city. J Environ Biol 27(2):419-421

72. Mýtinová Z, Haisel D, Wilhelmová N (2006) Photosynthesis and protective mechanisms during ageing in transgenic tobacco leaves with over-expressed cytokinin oxidase/dehydrogenase and thus lowered cytokinin content. Photosynthetica 44(4):599605. https://doi.org/10.1007/s11099-006-0078-6

73. Miller G, Suzuki N, Ciftci-Yilmaz S, Mittler R (2010) Reactive oxygen species homeostasis and signalling during drought and salinity stresses. Plant Cell Environ 33(4):453-467. https://doi. org/10.1111/j.1365-3040.2009.02041.x

74. Choudhury FK, Rivero RM, Blumwald E, Mittle R (2017) Reactive oxygen species, abiotic stress and stress combination. Plant J 90:856-867

75. Salehi-Lisar SY, Deljoo S (2015) The physiological effect of fluorene on Triticum aestivum, Medicago sativa, and Helianthus annus. Cogent Food Agric 1:1020189. https://doi.org/10.1080/ 23311932.2015.1020189

76. Kosová K, Vítámvás P, Urban MO, Prášil IT, Renaut J (2018) Plant abiotic stress proteomics: the major factors determining alterations in cellular proteome. Front Plant Sci 9:122. https://doi.org/ 10.3389/fpls.2018.00122

Publisher's Note Springer Nature remains neutral with regard to jurisdictional claims in published maps and institutional affiliations. 